\title{
Corrigendum: Germline KRAS mutations cause Noonan syndrome
}

Suzanne Schubbert, Martin Zenker, Sara L Rowe, Silke Böll, Cornelia Klein, Gideon Bollag, Ineke van der Burgt, Luciana Musante, Vera Kalscheuer, Lars-Erik Wehner, Hoa Nguyen, Brian West, Kam Y J Zhang, Erik Sistermans, Anita Rauch, Charlotte M Niemeyer, Kevin Shannon \& Christian P Kratz

Nat. Genet. 38, 331-336 (2006).

Individual 1 depicted in Figure 1a is shown at the age of 5 months, not at the age of 14 months, as stated in the legend. 